\title{
Feasibility of biodegradation of Azamethiphos; odour and fly controlling chemical used in open solid waste dumpsite at Karadiyana, Colombo, Sri Lanka
}

\author{
DSW Serasinghe and Pathmalal M Manage \\ Centre for Water Quality and Algae Research, Department Zoology, Faculty of Applied Sciences, University of Sri Jayewardenepura, Gangodawila, \\ Nugegoda.
}

\begin{abstract}
Azamethiphos (AZA) is an organophosphorus pesticide used to control flies and odour. Karadiyana is an open dumpsite in Colombo which creates problems like unpleasant odour and flies which have led to heavy use of AZA. Thus, the present study was aimed to isolate and characterize AZA degrading bacteria from the dumpsite. AZA was extracted from soil and water samples using the solid phase extraction method and quantified by the high-performance liquid chromatography. Soil and water recovery of AZA was recorded as $94.65 \pm$ $0.13 \mathrm{mg} \mathrm{L}^{-1}$ and $94.02 \pm 0.09 \mathrm{mg} \mathrm{L}^{-1}$, respectively. Partitioning coefficient values and high sorption coefficient values depicted AZA is likely to be in sorbed status combining with organic matter rather than being in an insoluble status. The bacteria; Bacillus graminis, Corynebacterium sp., Enterobactor sp., Micrococcus sp. and Lactobacillus sp. were identified as AZA degraders and complete removal of AZA was achieved at 10 days of incubation following the half-life time of $6,2,5,5$ and 3 days, respectively. The highest degradation rate $\left(0.681 \mathrm{~d}^{-1}\right)$ was recorded after 2 days of incubation with Corynebacterium sp. The most effective temperature was $33^{\circ} \mathrm{C}$ and Lactobacillus sp. showed efficient degradation of AZA compared to the other isolates. The photo-oxidation effect on the removal of AZA was found to be low (47\%) compared with bacteria degradation ( $85 \%)$. Hence, the result of the study showed that microbial degradation is the major path of removal of AZA from the environment considering only the natural routes of degradation.
\end{abstract}

Keywords: Azamethiphos (AZA), Corynebacterium sp., high-performance liquid chromatography (HPLC), microbial degradation, partitioning coefficient.

\section{INTRODUCTION}

As the world hurtles toward its urban future, the amount of solid waste is growing even faster than the rate of urbanisation. It has been estimated that the amounts of solid waste have increased about 3 billion tons to date and household residents generate $1.2 \mathrm{~kg}$ per person per day in the world (1.3 billion tons per year) (Zaman, 2016). High-income countries produce the highest solid waste per capita; while low-income countries produce the least solid waste per capita (Jouhara et al., 2017). Sri Lanka generates 7000 MT of solid waste per day within the Western Province accounting for nearly $60 \%$ of waste generation per day (Karunarathne, 2015). While per capita waste generation on an average is $1-0.4 \mathrm{~kg} /$ cap/day, only half of the waste generated is collected (Karunarathne, 2015). In 1999, the average per capita municipal solid waste generation was $0.89 \mathrm{~kg} / \mathrm{cap} /$ day and has been predicted to reach $1.0 \mathrm{~kg} / \mathrm{cap} /$ day by 2025 (Vidanaarachchi et al., 2006). Thus, solid waste disposal has become a major threat to the environment in most of the developing countries specially as the waste is pooled directly to open dumpsites. Sri Lanka currently faces the challenge arising from the absence of an integrated solid waste management system.

Public surveys revealed the worst impacts of the present open solid waste disposal practices to be related to

\footnotetext{
* Corresponding author (pathmalal@sjp.ac.lk; (iD https://orcid.org/0000-0002-2014-2060)
} 
social impacts such as bad odour, the spread of breeding grounds for insects and rodents, spreading of diseases and loss in property values near the dumpsites (Zaman, 2016). A major problem encountered is the odour and flies which affects the day-to-day lives of the neighbourhood. The emission of methane is another environmental problem that can be a cause of severe problems in the local environment including annoyance, health risks and bad odour. The increase of rats and rodents is the other identified problem (Bandara et al., 2007). To get rid of flies and rodents around the dumpsites, various types of pesticides such as mebendazole (Verminex), propoxur (Baygon), AZA (Zazacron), pyrethrin aerosol and alcohols, C12-14 and ethoxylated propoxylated (Odor Zorb) are used in open solid waste dumpsites.

Zazacron is a chemical which is highly used to control flies and odour problem, especially in open solid waste dumpsites. It contains Azamethiphos (AZA) which is an insecticide and also a pheromone attractant to housefly (Aulakh et al., 2005). AZA is an organophosphorus pesticide (OP) that acts as a cholinesterase inhibitor and is most commonly used to control flies and other insect pests in animal houses (Aulakh et al., 2005). AZA contamination and its persistence in soil and water environments, with bioaccumulation in cells of phytoplankton, zooplankton, fishes and vegetables have been reported (Aulakh et al., 2005). AZA has low acute oral and dermal mammalian toxicity when formulated as a $50 \%$ wettable powder. Signs of acute toxicity of AZA have been consistent with cholinesterase inhibition (Kohzaki et al., 1991). AZA can enter animal and human body via inhalation of contaminated air, ingestion of contaminated food and water or by dermal contact (Kohzaki et al., 1991).

In recent years, AZA has become a popular chemical among solid waste managers and is being continuously used at Karadiyana open dumpsite and the adjacent households to control flies and foul odour problem. Permanent residences in the area are located within 50 $\mathrm{m}$ of the Karadiyana dumpsite which is being operated within the premises of Boralasgamuwa-Borupana wetland adjacent to the Weras River. Therefore, the river water and the environment can easily get contaminated with the heavy use of AZA.

In order to minimize environmental risks originating from the presence of the pesticide, it would be judicious to develop effective technologies that ensure successful and simple degradation of these compounds
(Pergal et al., 2020). Biodegradation is an efficient green remediation method of many types of xenobiotic chemicals by microorganisms that grow in different ecosystems including incompatible extreme conditions (Sarnaik, 2004). It is one of the most promising methods for the treatment of pesticides as it is a cost-effective and environmentally friendly method and will lead to complete degradation of toxic substances.

A diverse group of bacteria, including members of the genera Alcaligenes, Flavobacterium, Pseudomonas and Rhodococcus has been recorded as potential candidates for biodegradation of different types of xenobiotics including pesticides worldwide (Aislabie \& Lloyd-Jones, 1995). To date, several organophosphorus compound-degrading bacteria species have been isolated from soil and aquatic environment (Sarnaik, 2004). The first bacteria that could degrade organophosphorus compounds was isolated in 1973 and identified as Flavobacterium sp. (Singh \& Walker, 2006). Similarly, different hydrocarbondegrading bacteria (Liyanage \& Manage, 2016a), POPs degrading bacteria (Idroos \& Manage 2018), textile degrading bacteria (Ekanayake \& Manage, 2017), and cyanotoxin degrading bacteria (Manage et al., 2009, 2016a; Idroos \& Manage, 2018) have been isolated from harsh environment including wastewater, petroleum oil-contaminated sites, polluted water, and solid waste dumpsites. Sarnaik (2004), Singh and Walker (2006), Singh (2009), Colorado et al. (2016) recorded Bacillus sp., Enterobactor sp. and Lactobacillus sp. as potential organophosphorus degrading bacteria. Recent studies have recorded the degradation potential of pesticides by the bacteria; Klebsiella pneumoniae pneumoniae, Pseudomonas alcaligenes and Enterobacter aerogenes which have been isolated from solid waste contaminated sites (Sarnaik, 2004; Melo et al., 2017). Thus, isolation, identification and characterisation of microorganisms with the ability to metabolize toxic chemicals are essential to establish microbes as an eco-friendly green solution for solid waste management programmes (Colorado et al., 2016).

Thus, the present study is aimed at isolating and characterising AZA degrading bacteria and to determine the partitioning coefficient of AZA in the ambient environment to understand the behaviour and bioaccumulation potential of the chemical AZA in order to recommend it for future application in open dumpsites. According to the author's knowledge, this is the first study on the microbial degradation of AZA. 


\section{MATERIALS AND METHODS}

\section{Study area}

\section{Karadiyana controlled solid waste dumpsite at Thumbovila}

The Karadiyana Waste Management Facility is located in Thumbovila (6 $488^{\prime} 58.32^{\prime \prime}$, 7954'9.90"E), North GN Division of Kesbawa Pradeshiya Saba and it is managed by the Western Province Waste Management Authority. Earlier the Karadiyana waste yard was a marshy land and the area is currently being used by seven Local Government Authorities; Moratuwa Municipal Council, Dehiwala-Mount Lavinia Municipal Council, Sri Jayewardenepura Kotte Municipal Council, Maharagama Urban Council, Panadura Urban Council, Kesbewa Urban Council and Boralegamuwa Urban Council, to dump organic and mixed solid waste at a daily average load of 457.14 MT. The Karadiyana open dump yard contains two waste dumpsites; Site A (4.85 ha) and site B (5.26 ha) and the total area of the site is 10.11 ha. One of the major environmental and ecological concerns of the Karadiyana open dumpsite is the pollution of Weras riverBolgoda lake system via leachate from the dumpsite. North and South Bolgoda lake basins are connected by the Weras river. Meda-Ela, a small canal that flows through Karadiyana open dumpsite intercepts the Weras river adjacent to the dumpsite. Leachate produced at the Karadiyana open dumpsites directly flows into the MedaEla and its water connect with Weras river-Bolgoda lake system. Thus, the dumpsite could be the major point source of pollution to the Bolgoda Lake (Dahanayaka et al., 2016).

Sample collection for physico-chemical analysis of soil, water and to isolate AZA degrading bacteria

The selection of soil and water sampling locations based on the application of AZA on the open solid waste dumpsite. Three soil samples from each sampling location named S1, S2 and S3 were randomly collected into sterile ziplock polypropylene bags and three water samples from each location; W1, W2 and W3 were collected into sterile glass bottles from the Weras-stream which flows at the edge of the dumpsite. Samples were stored in an icebox and transferred to the laboratory within three hours and kept at $4{ }^{\circ} \mathrm{C}$ until analysis. Temperature and $\mathrm{pH}$ of soil and water were measured at the site itself using portable meters and $\mathrm{N}-\mathrm{NO}_{3}{ }^{-}$and $\mathrm{T}-\mathrm{PO}_{4}{ }^{3-}$ were measured using the standard spectrophotometric method (APHA, 1999). The organic carbon content was measured by modified Walkley-Blacky titration method.

\section{Extraction of AZA from contaminated soil and water}

Collected soil samples were air-dried at room temperature and were pulverized and sieved through $250 \mu \mathrm{m}$ sieve. AZA treated soil $(1.00 \mathrm{~g})$ was loaded into $50 \mathrm{~mL}$ centrifuge tube and the AZA was extracted into $10 \mathrm{~mL}$ of HPLC grade Acetonitrile by shaking at a rate of 250 $\mathrm{rpm}$ in a mechanical shaker for $3 \mathrm{~min}$. Then, the resultant slurry solution was centrifuged at $3500 \mathrm{rpm}$ for $5 \mathrm{~min}$ and the supernatant was collected and filtered through 0.45 $\mu \mathrm{m}$ membrane filter (Yang et al., 2012). The procedure was carried out three times to ensure complete extraction of AZA from soil. Then the filtration was subjected to Solid Phase Extraction (SPE) using C18 (EC 1 g 3 mL Biotahe) column followed by rotary evaporation and the resultant residue was re-suspended in $1 \mathrm{~mL}$ of HPLC grade Acetonitrile-Mili Q water (20:80, v/v) and filtered $(0.2 \mu \mathrm{m})$ prior injecting to the HPLC system (Baskaran et al., 1997).

Collected water samples (50 mL per sample) were also subjected to SPE using a C18 column. The C18 column was conditioned by passing filter-sterilized Mili Q water for 5 min and then the collected water sample was passed through the conditioned $\mathrm{C} 18$ column maintaining

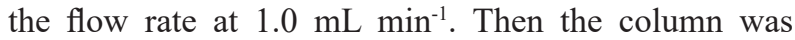
allowed to dry for $15 \mathrm{~min}$ and eluted with $2 \mathrm{~mL}$ of 100 $\%$ methanol. The methanol elute was subjected to rotary evaporation at $44.4{ }^{\circ} \mathrm{C}$ and the resultant residue was redissolved in $2 \mathrm{~mL}$ of HPLC grade Acetonitrile-Mili Q water $(20: 80 \mathrm{v} / \mathrm{v})$ for quantification of AZA.

Quantification of AZA was carried out using the HPLC system consisting of Agilent 1200 series (Column size $-3.5 \mu \mathrm{m} \times 4.6 \times 100 \mathrm{~mm}$ ). Two mobile phases were optimised for the isocratic run (Acetonitrile: water = 70:30). The sample volume of $25 \mu \mathrm{L}$ was injected at a flow rate of $1 \mathrm{~mL} \mathrm{~min}{ }^{-1}$ and the concentration of AZA was determined by the peak area (at $294 \mathrm{~nm}$ ) referring to the calibration curve. The detection limit of AZA was found to be $1 \mathrm{mg} \mathrm{L}^{-1}$.

\section{Method optimisation and preparation of the calibration for AZA}

The concentration of AZA was quantified using the equation derived from the calibration plot prepared for standard AZA using the dilution series ranging from 5 $\mathrm{mg} \mathrm{L}^{-1}$ to $250 \mathrm{mg} \mathrm{L}^{-1}$. The peak area of the sample for specific retention time, the slope and the intercept of the calibration curve were used to calculate the concentration of AZA in unknown samples. The following equation was used to calculate the AZA. 
$\mathrm{x}=(\mathrm{y}-160.48) / 39.669$

Where, $\mathrm{x}=$ concentration $\left(\mathrm{mg} \mathrm{L}^{-1}\right)$ and $\mathrm{y}=\operatorname{area}(\mathrm{mAu} \times$ $\min$ )

\section{Recovery test}

The recovery test for water was carried out as follows; $50 \mathrm{~mL}$ of sterilised Mili Q water was spiked with AZA at a final concentration of $100 \mathrm{mg} \mathrm{L}^{-1}$. For soil samples, sterilised $1 \mathrm{~g}$ of soil was mixed with $50 \mathrm{~mL}$ of Mili Q water and spiked with AZA at a final concentration of $100 \mathrm{mg} \mathrm{L}^{-1}$. Both water and soil samples were subjected to SPE through a C18 cartridge. Extraction and quantification of AZA were done using the method described above.

\section{Determination of soil: water partitioning coefficient (Kd) of AZA}

Collected soil samples were air-dried, homogenised and sieved through a $250 \mu \mathrm{m}$ sieve. A $100 \mathrm{mg} \mathrm{L}^{-1}$ concentration AZA solution was prepared in $0.01 \mathrm{M}$ calcium chloride to maintain constant ionic strength (Konda et al., 2002). Each sample consisting of $5 \mathrm{~g}$ of soil was mixed with $25 \mathrm{~mL}$ of AZA solution in $50 \mathrm{~mL}$ polypropylene centrifuge tubes subjected to agitate on a rotary shaker for $24 \mathrm{~h}$ at $20 \pm 1{ }^{\circ} \mathrm{C}$ to achieve equilibrium. Blanks without soil were prepared in a similar manner which showed no adsorption of pesticides on the walls of the tube. Once equilibrium was achieved, the concentration of AZA associated with the solids and dissolved fractions were measured followed by centrifugation at $3600 \mathrm{rpm}$ for $30 \mathrm{~min}$. Quantification of AZA was done using the method described above. The following equation was used to calculate the partitioning coefficient $\left(\mathrm{K}_{\mathrm{d}}\right)$ of AZA in vitro.

$\mathrm{K}_{\mathrm{d}}=[$ Sorbed AZA concentration $] /[$ AZA concentration
in water $]$

Where the $\mathrm{K}_{\mathrm{d}}$ values given below indicate the behaviour of AZA in water and soil compartment; $\mathrm{K}_{\mathrm{d}}=1$; equally distributed between solid and water, $\mathrm{K}_{\mathrm{d}}>1$; more than $50 \%$ likely present in sorbed states, $\mathrm{K}_{\mathrm{d}}>>1$; most present is highly sorbed, very little in the soluble state (water), $\mathrm{K}_{\mathrm{d}}<1$; more than $50 \%$ likely present in soluble state (water column), $\mathrm{K}_{\mathrm{d}}<<<1$; most present in a highly soluble state, very little sorbed.

The partitioning coefficient was determined under laboratory conditions and it would vary depending on the ratio of soil to water and the chemical properties of both pesticide and soil. Therefore, the sorption characteristics of a pesticide can be normalised to obtain a general soil sorption constant $\left(\mathrm{K}_{\mathrm{OC}}\right)$ based on the organic carbon content to all soil types (Kanazawa, 1989). Thus, the following equation was used to calculate the Koc.

$\mathrm{K}_{\mathrm{OC}}=[$ Partitioning coefficient / [Amount of organic $\left.\left(\mathrm{K}_{\mathrm{d}}\right)\right] \quad$ carbon in the soil $\left.(\mathrm{g})\right]$

The organic carbon content of the soil is directly proportionate to the organic matter of soil which is primarily responsible for sorption properties of the soil. Organic carbon content is a primary decisive characteristic for the determination of economic potential of the deposits (Gelman et al., 2012). Higher the $\mathrm{K}_{\mathrm{OC}}$ value, the more strongly the pesticide is sorbed, which means the mobility is low (Kanazawa, 1989).

To ascertain the AZA degradation in vitro, maintaining constant ionic strength is important. Thus, an AZA solution in $0.01 \mathrm{M} \mathrm{CaCl}_{2}$ and another tap water treated AZA were prepared (Kanazawa, 1989). Both preparations were shaken side-to-side simultaneously. Extraction and determination of AZA concentration were done using the method described above. AZA concentrations in the two phases were detected after $12 \mathrm{~h}, 24 \mathrm{~h}$ and $36 \mathrm{~h}$ until equilibrium is reached.

\section{Isolation of AZA degrading bacteria}

Soil for the enrichment study was prepared by adding $5 \mathrm{~g}$ of well-mixed soil sample into $50 \mathrm{~mL}$ of water in $250 \mathrm{~mL}$ Erlenmeyer flasks. A similar procedure was followed for water by adding $50 \mathrm{~mL}$ of water into $250 \mathrm{~mL}$ Erlenmeyer flasks. To enrich bacteria which can degrade AZA, $25 \mathrm{mg}$ of AZA was added into the flask and the final volume was topped up to $100 \mathrm{~mL}$ using sterile Milli-Q water to obtain $250 \mathrm{mg} \mathrm{L}^{-1}$ of AZA as the final concentration and then the flasks were incubated at shaking conditions (Model: KS 4000i, UK), at $25 \pm{ }^{\circ} \mathrm{C}$ and $100 \mathrm{rpm}$ for $14 \mathrm{~d}$ (Manage et al., 2009; Liyanage \& Manage, 2016a). After $14 \mathrm{~d}$ of incubation, $1 \mathrm{~mL}$ of subsamples were collected and isolation of AZA degrading bacteria was carried out by preparing a dilution series using sterilized $0.9 \%$ saline solution followed by standard pour plate method (Liyanage \& Manage, 2016a; Manage et al., 2016a; Idroos \& Manage 2018). After 3 d of incubation at room temperature $\left(25 \pm 1{ }^{\circ} \mathrm{C}\right)$, bacterial colonies with different morphological characteristics were selected to isolate and re-suspended in liquid LB medium and pure cultures were prepared by repeated streaking of the bacterium on LB agar (1.5\%) plates (Liyanage \& Manage, 2016b; Manage et al., 2016a). The pure bacterial cultures were 
subcultured and stored in agar slants at $-20^{\circ} \mathrm{C}$ in LBglycerol media for further studies (Manage et al., 2009).

\section{Determination of degradation of AZA}

A loop of isolated bacterial strains grown overnight at dark in liquid LB medium were centrifuged at 8000 rpm for 15 min following three times wash procedure with $0.9 \%$ saline (Manage et al., 2009) to ensure that the carbon source in the growth medium was exhausted. Thereafter, the bacterial cells were starved overnight in $0.9 \%$ saline (Idroos \& Manage, 2018) and turbidity was equalised to 0.350 at $590 \mathrm{~nm}$ wavelength of using the UV-Vis spectrophotometer to get a more or less similar number of bacterial cells $\left(1-2 \times 10^{8}\right.$ cells $\left./ \mathrm{mL}\right)$ (Manage et al., 2000; 2016b).

Then the bacterial suspension was inoculated in to filter-sterilized water $(0.22 \mu \mathrm{m})$ containing AZA at the final concentration of $250 \mathrm{mg} \mathrm{L}^{-1}$. The treated flasks were incubated at $28{ }^{\circ} \mathrm{C}$ and $1 \mathrm{~mL}$ aliquot was taken for $14 \mathrm{~d}$ at $2 \mathrm{~d}$ interval. The concentration of AZA in each sample was measured using the method described above. A control was prepared which was treated in the same manner without bacterial inoculation (Manage et al., 2009; Liyanage \& Manage, 2016b).

\section{Characterization and identification of bacterial isolates}

The bacterial isolates were subjected to Gram stain following biochemical tests for tentative identification. Confirmation of the bacteria identification was done by 16S rRNA gene sequence analysis (Liyanage \& Manage, 2016b).

\section{Degradation kinetics of the isolated bacteria}

All the potential AZA degrading bacterial isolates were tested against $250 \mathrm{mg} \mathrm{L}^{-1}$ concentration of AZA, and subsamples to determine bacteria degradation was collected at $2 \mathrm{~d}$ intervals for $14 \mathrm{~d}$. The AZA degradation rates $(h)$ of the isolated bacteria were calculated using the equation given below;

$\mathrm{h}=\ln \left(\mathrm{C} / \mathrm{C}_{0}\right) / \mathrm{t}$

Where ' $\mathrm{C}_{0}$ ' and ' $\mathrm{C}$ ' are the concentrations of AZA at the beginning and at the end of the time interval ' $\mathrm{t}$ ', respectively (Manage et al., 2000). The degradation of AZA by bacteria was confirmed by HPLC analysis and the half lifetime of the bacteria was calculated as the time taken to degrade $50 \%$ of AZA using the results of the degradation kinetics study.

\section{Optimisation of environmental factors}

Effect of temperature and nutrient concentration (nitrate and phosphate) were determined using different temperatures $\left(23,28\right.$ and $\left.33{ }^{\circ} \mathrm{C}\right)$ and nutrient concentrations. The effect of phosphate was determined to supplement with $\mathrm{KH}_{2} \mathrm{PO}_{4}$ at $0.002 \mathrm{mg} \mathrm{L}^{-1}$ and $0.05 \mathrm{mg} \mathrm{L}^{-1}$ concentrations whereas the effect of nitrate was determined with $\mathrm{NH}_{4} \mathrm{NO}_{3}$ enriched water with varying concentrations $\left(0.05-0.15 \mathrm{mg} \mathrm{L}^{-1}\right)$ of nitrate (Liyanage \& Manage, 2016b).

\section{Determination of photodegradation of AZA}

Effect of light on the degradation of AZA was tested exposing the AZA to sunlight and the control was kept in dark providing the same environmental conditions. The study was compared with the addition of bacteria into a similar experimental setup for a similar time span. In this study, $5 \mathrm{~g}$ of soil was weighed and mixed with water. AZA was added at the final concentration of $250 \mathrm{mg} \mathrm{L}^{-1}$. Triplicate samples were kept in dark and under direct sunlight with and without bacteria inoculation to evaluate the effect of sunlight and the combined effect of the bacterial isolates with sunlight.

\section{RESULTS AND DISCUSSION}

\section{Physico-chemical parameters}

Microbial degradation of any chemical compound is influenced by the physical, chemical and biological environment (Liyanage \& Manage, 2016a; Manage et al., 2016a). In general, microbial degradation of xenobiotics is enzyme-mediated and the microbial process of chemical remediation depends on the favourable physical and chemical condition of the ambient environment. Thus, temperature and $\mathrm{pH}$ of the environment are considered critical factors that influence microbial degradation.

Table 1: Mean temperature, $\mathrm{pH}, \mathrm{N}-\mathrm{NO}_{3}{ }^{-}$and $\mathrm{T}_{-} \mathrm{PO}_{4}{ }^{3-}$ of water samples

\begin{tabular}{ccccc}
\hline Sample & \multicolumn{4}{c}{ Parameters } \\
& $\begin{array}{c}\text { Temperature } \\
\left({ }^{\circ} \mathrm{C}\right)\end{array}$ & $\mathrm{pH}$ & $\begin{array}{c}\mathrm{N}^{-\mathrm{NO}_{3}}{ }^{-} \\
\left(\mathrm{mg} \mathrm{L}^{-1}\right)\end{array}$ & $\begin{array}{c}\mathrm{T}^{-}-\mathrm{PO}_{4}{ }^{3-} \\
\left(\mathrm{mg} \mathrm{L}^{-1}\right)\end{array}$ \\
\hline $\mathrm{W} 1$ & 28.4 & 6.95 & 0.12 & 0.01 \\
$\mathrm{~W} 2$ & 28.5 & 7.01 & 0.10 & 0.02 \\
$\mathrm{~W} 3$ & 28.6 & 6.88 & 0.11 & 0.01 \\
Mean $\pm \mathrm{SD}$ & $28.5 \pm 0.10$ & $6.95 \pm 0.07$ & $0.11 \pm 0.01$ & $0.01 \pm 0.01$ \\
\hline
\end{tabular}


More or less similar variations of physico-chemical parameters of surface water in the Weras River were recorded (Table 1). Surface water temperature ranged from $28.4^{\circ} \mathrm{C}$ to $28.6^{\circ} \mathrm{C}$ while the $\mathrm{pH}$ ranged from 6.88 7.01. These are favourable environmental conditions which enhances microbial growth and activities. The

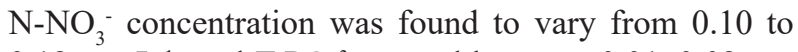
$0.12 \mathrm{mg} \mathrm{L}^{-1}$, and T-PO ${ }_{4}^{3-}$ ranged between $0.01-0.02 \mathrm{mg}$ $\mathrm{L}^{-1}$ (Table 1 ). All the recorded water quality parameters were below the standards given for $\mathrm{N}^{-\mathrm{NO}_{3}}{ }_{3}^{-}\left(10 \mathrm{mg} \mathrm{L}^{-1}\right)$ and $\mathrm{T}^{-\mathrm{PO}_{4}{ }^{3-}}\left(0.4 \mathrm{mg} \mathrm{L}^{-1}\right)$ by the $\mathrm{CEA}$ guideline for aquatic life. The recorded ranges of water temperature and $\mathrm{pH}$ were found to be most suitable for bioremediation of AZA according to the studies reported by Manage et al. (2009; 2016a; b). Colorado et al. (2016); Liyanage and Manage (2016b); Ekanayake and Manage (2017); Idroos and Manage (2018) recorded more or less similar range of temperature and $\mathrm{pH}$ for degradation of cyanotoxins, PHAs and crude hydrocarbon in the environment. Furthermore, nutrients such as nitrate and phosphorus have a strong influence on microbial degradation of xenobiotics (Manage et al., 2016a; b; Uqab et al., 2016). Scarcity of essential nutrients such as nitrogen, phosphorous and Terminal Electron Acceptors (TEAs) have been recognised as crucial factors that inhibit microbial bioremediation performance (Roy et al., 2018). Nitrate is one of the essential nitrogen components in the biosphere serving as an important nutrient and electron acceptor for microorganisms (Xu et al., 2014), and changes in the amount of nitrate and phosphate in the environment directly effect microorganism community and activity (Ekanayake \& Manage, 2017; Idroos \& Manage, 2018,). Kalantary et al. (2014) reported that phosphorus was the dominant macronutrient in the bioremediation of PAH. Thus, anthropogenic impacts on changes in nutrient composition in the environment directly or indirectly affect the microbial composition and density in soil and water (Roy et al., 2018).

In the present study, the soil of the sampling sites was found to be sandy loam and $\mathrm{pH}$ ranged from 8.23 to 8.26 where variation of soil temperatures was slight and the mean temperature was recorded as $27.30 \pm 0.13{ }^{\circ} \mathrm{C}$. The average moisture content of the soil was $0.08 \pm 0.00 \mathrm{~g}$ and organic content was as low as $0.0047 \mathrm{~g}$ per $1 \mathrm{~g}$ of soil (Table 2).

Table 2: Mean temperature, $\mathrm{pH}$, moisture, organic content and texture of soil samples

\begin{tabular}{cccccc}
\hline Sample & Temp. $\left({ }^{\circ} \mathrm{C}\right)$ & $\mathrm{pH}$ & $\begin{array}{c}\text { Parameters } \\
\text { Moisture content } \\
(\mathrm{g}) \text { per 1 g of soil }\end{array}$ & $\begin{array}{c}\text { Organic } \\
\text { content }(\mathrm{g})\end{array}$ & Texture \\
\hline S 1 & 27.2 & 8.25 & 0.0773 & 0.0052 & Sandy loam \\
S 2 & 27.4 & 8.26 & 0.0775 & 0.0047 & Sandy loam \\
S 3 & 27.4 & 8.23 & 0.0772 & 0.0049 & Sandy loam \\
Mean \pm SD & $27.3 \pm 0.13$ & $8.25 \pm 0.02$ & $0.08 \pm 0.00$ & $0.00 \pm 0.00$ & \\
\hline
\end{tabular}

Uqab et al. (2016) recorded that microbial degradation of pesticides is governed by the moisture content or the water holding capacity of the soil (25-28\%) and the nature of soil such as low clay or silt content. However, in the present study, the moisture content of the soil was $0.08 \mathrm{~g}$ per $1 \mathrm{~g}$ of soil and the soil texture was sandy loam. Further, the recorded organic content of the soil was very low ( $0.0047 \mathrm{~g}$ per $1 \mathrm{~g}$ of soil). Microorganisms are present virtually everywhere in nature and survive in extreme conditions of $\mathrm{pH}$, temperature, pressure, nutrient content, water content, and salinity (Ray, 2014). Thus, the results gained from the present study were favourable for the biodegradation although the results showed low moisture and organic content. According to Ray (2014), when the environmental conditions are conducive, the process of biodegradation may occur without any human intervention and does not involve human exposure to the chemicals.

\section{Determination of AZA concentration}

In the present study, optimisation of a modified method to quantify AZA, bacteria degradation of AZA and photodegradation of AZA in the dumpsite was evaluated. The results of the study may be important for future recommendation of AZA as a fly control chemical for open solid waste dumpsites. A detection and quantification method for AZA is not available in Sri Lanka at present and it is important to establish a cost-effective method to monitor the contamination level of AZA as a pesticide which is being applied to get rid of flies in open dumpsites. In the present study, 
reversed-phase HPLC method was used to detect the AZA in environmental samples. The concentration of AZA was quantified using the equation given below which is derived from the calibration plot prepared for the standards of AZA. The peak area of the sample for specific retention time, the slope and the intercept of the calibration curve were used to calculate the concentration of AZA in unknown samples. The derived equation from the calibration curve is given below,

$\mathrm{x}=(\mathrm{y}-160.48) / 39.669$

Where, $\mathrm{x}=$ concentration $\left(\mathrm{mg} \mathrm{L}^{-1}\right)$ and $\mathrm{y}=$ area $(\mathrm{mAu} \times$ $\min$ )

The calibration curve obtained by plotting peak area $(\mathrm{mAu} \times \mathrm{min})$ versus concentrations $\left(\mathrm{mg} \mathrm{L}^{-1}\right)$ of AZA showed excellent linearity with correlation coefficient $\left(\mathrm{R}^{2}=0.996\right)$. Hence, a strong relationship was found between peak areas against concentrations of AZA. The recoveries of AZA in water and soil samples were detected as $94.02 \pm 0.09 \mathrm{mg} \mathrm{L}^{-1}$ and $94.65 \pm 0.13 \mathrm{mg} \mathrm{L}^{-1}$, respectively. Recovery test results were higher than $94 \%$ which confirmed the validity and reliability of the optimised extraction and detection methods for AZA. HPLC-UV was found in previous studies to be suitable for the determination of the AZA in water samples showing linearity with the correlation coefficient $\left(\mathrm{R}^{2}=0.9384\right)$ in the calibration plot (Aulakh et al., 2005).

\section{Determination of partitioning coefficient $\left(K_{d}\right)$ and sorption coefficient $\left(K_{o c}\right)$}

The partitioning coefficient values decreased over time due to the movement of weakly sorbed pesticide particles through the soil profile to water (Table 3). However, after 24 hours, the concentration of AZA reached an equilibrium in both liquid and soil phase and then no movement of the pesticide particles was evident. Table 3 shows the mean values of partitioning and sorption coefficients. The $\mathrm{K}_{\mathrm{d}}$ values which are higher than 1 indicates more than $50 \%$ is likely to be present in sorbed status rather than being in soluble state.

Table 3: Mean values of partitioning coefficient and sorption coefficient

\begin{tabular}{lcccccc}
\hline Sample & \multicolumn{3}{c}{ Partitioning coefficient $\left(\mathrm{K}_{\mathrm{d}}\right)$} & \multicolumn{3}{c}{ Sorption coefficient $\left(\mathrm{K}_{\mathrm{oc}}\right)$} \\
& $12 \mathrm{hrs}$ & $24 \mathrm{hrs}$ & $36 \mathrm{hrs}$ & $12 \mathrm{hrs}$ & $24 \mathrm{hrs}$ & $36 \mathrm{hrs}$ \\
\hline Sterilized soil $+\mathrm{CaCl}_{2}$ & 2.53 & 1.94 & 1.90 & 510.01 & 390.70 & 383.49 \\
Non-sterilized $+\mathrm{CaCl}_{2}$ & 2.67 & 2.03 & 1.84 & 538.16 & 409.61 & 371.77 \\
Sterilized soil + water & 2.30 & 1.57 & 1.70 & 464.42 & 316.80 & 343.48 \\
Non-sterilized soil + water & 2.07 & 1.63 & 1.62 & 416.73 & 329.53 & 327.38 \\
\hline
\end{tabular}

Sorption describes the attraction between a chemical and soil, vegetation, or other surfaces (Nkedi-Kizza et al., 1985) and sorption most often refers to the binding of a chemical to soil particles (Nkedi-Kizza et al., 1985). Pesticides that sorb weakly to soil particles are more likely to move through the soil profile via infiltration to water (Nayanthika et al., 2018). In this study the sorption coefficient $\left(\mathrm{K}_{\mathrm{OC}}\right)$ values were relatively high in each soil sample (Table 3) which depicts that a high amount of pesticides is likely to be in sorbed status combining with the organic matter. Soil organic carbon content is primarily responsible for the soil sorption properties (Konda et al., 2002). However, referring to the results of the present study, infiltrating ability of AZA is low (Table 3$)$ and sorption coefficient $\left(\mathrm{K}_{\mathrm{OC}}\right)$ values are relatively higher (Table 3 ) indicating the high binding capacity of the chemical to the soil. No significant difference $(\mathrm{p}$ value $=0.185)$ was found in AZA concentrations in soil and liquid phase, when using $\mathrm{CaCl}_{2}$ and water as the liquid phase separately.

\section{Characterisation and identification of bacteria}

In the study, 20 bacteria strains were identified as AZA degraders during the primary screening. Among the bacterial isolates, if a strain showed $95 \%$ to $100 \%$ degradation of AZA it was selected as a potential AZA degrader for further studies. Based on morphological characteristics, biochemical tests and 16S rRNA gene sequence analysis, bacterial strains KD-S-2 (Bacillus graminis), KD-S-3 (Corynebacterium sp.), KD-S-5 (Enterobactor sp.), KD-S-6 (Micrococcus sp.) and KD-S-9 (Lactobacillus sp.) were identified as the potential candidates of AZA degradation. 
Several organophosphorus compounds degrading microorganisms have been isolated from diverse environments (Aislabie \& Lloyd-Jones, 1995; Sarnaik, 2004; Ray, 2014; Kafilzadeh et al., 2015). Singh (2009) recorded the bacteria genera Bacillus sp., Enterobactor sp. and Lactobacillus sp. as potential organophosphorus degraders and other studies have also reported the same bacteria as organophosphorus compound degraders (Sarnaik, 2004; Singh \& Walker, 2006; Colorado et al., 2016).

\section{Degradation kinetics}

Degradation of AZA by different bacteria strains is given in Figure 1. Complete degradation of the AZA by Enterobactor sp., Micrococcus sp. and Lactobacillus sp. was achieved at 6 days of incubation. The control experimental setup of the study showed no significant loss of AZA. The slight decrease found $(6.5 \%)$ may be due to the influence of some physical factors. Thus, the results of the study confirmed that the observed removal of AZA was due to bacterial remediation.

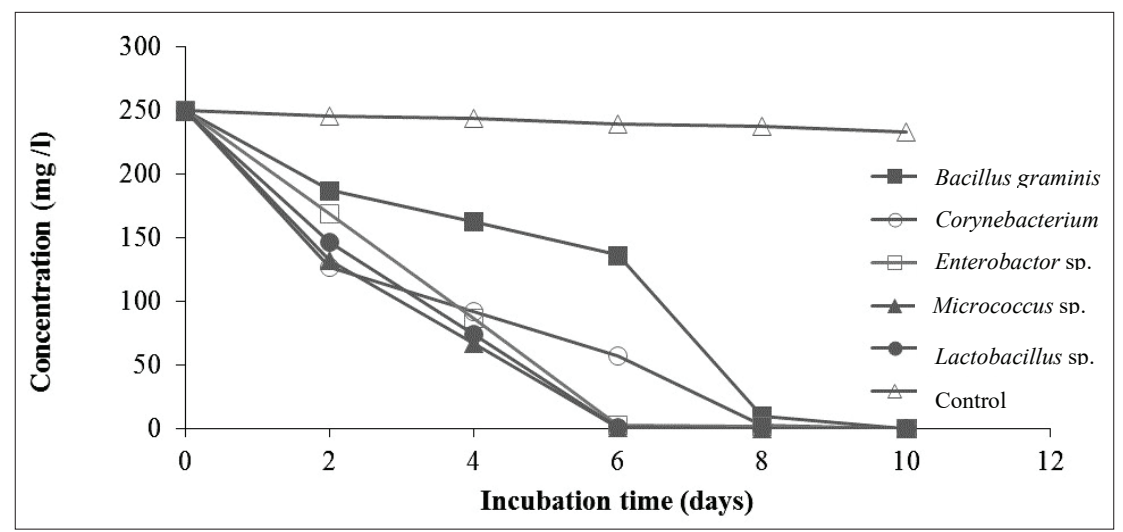

Figure 1: Degradation of AZA by isolated bacterial strains. When error bars are not shown, the standard deviation was less than the width of the symbol.

Table 4: Degradation rate of AZA by isolated bacteria

\begin{tabular}{|c|c|c|c|c|c|c|}
\hline \multirow[b]{2}{*}{$\begin{array}{l}\text { Incubation } \\
\text { time (Day) }\end{array}$} & \multicolumn{5}{|c|}{ Degradation rate of AZA by bacteria $\left(\right.$ day $\left.^{-1}\right)$} & \multirow[b]{2}{*}{ Control } \\
\hline & Bacillus sp. & Corynebacterium sp. & Enterobactor sp. & Micrococcus sp. & Lactobacillus sp. & \\
\hline 0 & 0 & 0 & 0 & 0 & 0 & 0 \\
\hline 2 & $0.1444 \pm 0.008$ & $0.6810 \pm 0.007$ & $0.1973 \pm 0.011$ & $0.3179 \pm 0.003$ & $0.2683 \pm 0.003$ & $0.0085 \pm 0.004$ \\
\hline 4 & $0.1074 \pm 0.006$ & $0.2500 \pm 0.004$ & $0.2654 \pm 0.004$ & $0.3311 \pm 0.003$ & $0.3057 \pm 0.004$ & $0.0201 \pm 0.002$ \\
\hline 6 & $0.1009 \pm 0.002$ & $0.2456 \pm 0.001$ & $0.8111 \pm 0.004$ & $0.9817 \pm 0.004$ & $1.3479 \pm 0.002$ & $0.0098 \pm 0.003$ \\
\hline 8 & $0.4077 \pm 0.004$ & $0.5975 \pm 0.001$ & $0.6098 \pm 0.002$ & $1.0284 \pm 0.001$ & $0.8188 \pm 0.001$ & $0.0137 \pm 0.004$ \\
\hline 10 & 0.000 & $1.1223 \pm 0.001$ & $1.0531 \pm 0.001$ & $0.9615 \pm 0.004$ & 0.000 & $0.0135 \pm 0.005$ \\
\hline 12 & 0.000 & 0.000 & 0.000 & 0.000 & 0.000 & $0.0166 \pm 0.003$ \\
\hline 14 & 0.000 & 0.000 & 0.000 & 0.000 & 0.000 & $0.0159 \pm 0.002$ \\
\hline
\end{tabular}

Corynebacterium sp. showed the highest degradation rate $\left(0.681 \mathrm{~d}^{-1}\right)$ after two days of incubation where Micrococcus sp., Lactobacillus sp. and Enterobactor sp., followed descending order of degradation as $0.3179 \mathrm{~d}^{-1}$,
$0.2683 \mathrm{~d}^{-1}$ and $0.1973 \mathrm{~d}^{-1}$, respectively (Table 4). The lowest degradation of $0.1444 \mathrm{~d}^{-1}$ after two days of incubation was shown by the Bacillus sp. 
Table 5: Half-lifetime of AZA degradation by different bacterial isolates

\begin{tabular}{lc}
\hline Bacterial isolate & Half-lifetime (Days) \\
\hline Bacillus sp. & 6 \\
Corynebacterium sp. & 2 \\
Enterobactor sp. & 5 \\
Micrococcus sp. & 5 \\
Lactobacillus sp. & 3 \\
\hline
\end{tabular}

The lowest half-lifetime of 2 days was recorded by the bacterium Corynebacterium sp. following 5, 5 and 3 days by Enterobactor sp., Micrococcus sp. and Lactobacillus sp., respectively. A half-lifetime of 6 days was to be found for the bacterium Bacillus sp. (Table 5).

\section{Optimisation of environmental factors}

In different studies, different bacterial strains have been employed and various degradation rates for organophosphorus compounds have been found (Singh, 2009; Liyanage \& Manage 2016a). The biochemistry of organophosphorus compound degradation by most of the bacteria seems to be identical, in which a structurally similar enzyme called organophosphate hydrolase or phosphotriesterase catalysis are involved in the first step of the degradation (Singh \& Walker, 2006). Many studies indicate that temperature is an important variable that determines the efficient degradation of organophosphates in contaminated water and soil (Colorado et al., 2016). Alberty (2011) recorded that the enzymatic activity of bacteria can be changed with temperature changes.

Concerning the overall degradation patterns of each bacterial isolate in different temperatures, the highest reduction of AZA after 14 days of incubation was found at $33{ }^{\circ} \mathrm{C}$ compared to temperatures of $23{ }^{\circ} \mathrm{C}$ and $28{ }^{\circ} \mathrm{C}$ for each bacterial isolate. After 14 days of incubation, all the bacterial isolates were able to degrade $100 \%$ of AZA at $33{ }^{\circ} \mathrm{C}$. The highest degradation $(94 \%)$ at $23{ }^{\circ} \mathrm{C}$ was shown by the bacterium Lactobacillus sp.

The results of the present study showed that all the bacterial isolates have maximum degradation at $33{ }^{\circ} \mathrm{C}$. Thus, it was clear that different bacterial isolates showed different degradation rates at different temperatures. Also, the results of the present study indicated that 33 ${ }^{0} \mathrm{C}$ temperature provides a favourable environment for the bacteria to grow faster which enhances the bioremediation of AZA.
For the growth of bacteria, carbon is the basic form of nutrient required. In addition to this, macro and micronutrients such as phosphorus and nitrogen are used to ensure an effective degradation of pesticides (Uqab et al., 2016).

A similar degradation pattern was found along with different nitrate concentrations; $0.05 \mathrm{mg} \mathrm{L}^{-1}$, $0.12 \mathrm{mg} \mathrm{L}^{-1}$ and $0.15 \mathrm{mg} \mathrm{L}^{-1}$ for all the bacterial isolates. Lactobacillus sp. showed the highest reduction (96\%) with $0.15 \mathrm{mg} \mathrm{L}^{-1}$ nitrate concentration whereas $94 \%$ and $91 \%$ of degradation were detected when the medium was supplemented with $0.12 \mathrm{mg} \mathrm{L}^{-1}$ and $0.05 \mathrm{mg} \mathrm{L}^{-1}$ concentration of nitrate, respectively at 14 days of incubation. Concerning the overall degradation pattern of bacterial isolates at different nitrate concentrations, the highest reduction of AZA recorded after 14 days of incubation was $0.15 \mathrm{mg} \mathrm{L}^{-1}$.

A similar degradation pattern was detected along with the different $\mathrm{T}_{-} \mathrm{PO}_{4}^{3-}$ concentrations of $0.002 \mathrm{mg}$ $\mathrm{L}^{-1}, \mathrm{t}$ and $0.05 \mathrm{mg} \mathrm{L}^{-1}$ for different bacterial isolates. Lactobacillus sp. showed the highest degradation (97\%) when phosphate concentration was $0.05 \mathrm{mg} \mathrm{L}^{-1}$, whereas $94 \%$ and $91 \%$ of degradation resulted when the medium was supplemented with phosphate concentrations of $0.01 \mathrm{mg} \mathrm{L}^{-1}$ and $0.002 \mathrm{mg} \mathrm{L}^{-1}$, respectively at 14 days of incubation. All the isolated bacterial strains showed the highest degradation percentage at $0.05 \mathrm{mg} \mathrm{L}^{-1}$ following $0.02 \mathrm{mg} \mathrm{L}^{-1}$ and $0.001 \mathrm{mg} \mathrm{L}^{-1}$.

In the present study, when nitrate and phosphate amounts in samples were considered, most of the values were much lower. But bacteria can adapt to different environmental conditions when they are exposed to the same conditions for a long time. Therefore, the isolates in the present study may be adapted to low nutrient conditions and not affected by the addition of nutrients. Nevertheless, Lactobacillus sp. showed relatively higher degradation patterns when compared with other bacterial isolates in higher phosphate and nitrate concentrations.

\section{Photodegradation of AZA}

Pesticides naturally degrade in the environment by photodegradation, oxidation and biodegradation. Remarkable degradation of AZA was achieved under different conditions of UV light (81\%), sunlight (47\%) and dark (2\%) (Figure 4a). When the soil samples were inoculated with the isolated bacterium Corynebacterium sp., drastic degradation of AZA was achieved at 14 days of incubation at different treatment set up. UV light with the bacterial treatment showed the highest degradation 
of $90 \%$ followed by sunlight with the bacterium $(70 \%)$ and dark environment with the bacterium (60\%) (Figure $2 b)$. However, the degradation percentage of AZA was recorded to be low when AZA was treated with only UV light (70\%), sunlight (47\%) and dark environment $(2 \%)$ (Figure $2 a)$. Thus, the results of the present study suggest that photodegradation also has an impact on the degradation of AZA in soil although other environmental factors such as rain, physical substrates on soil may influence the process. The effects of chemical oxidation and microbial degradation influence the degradation of AZA.

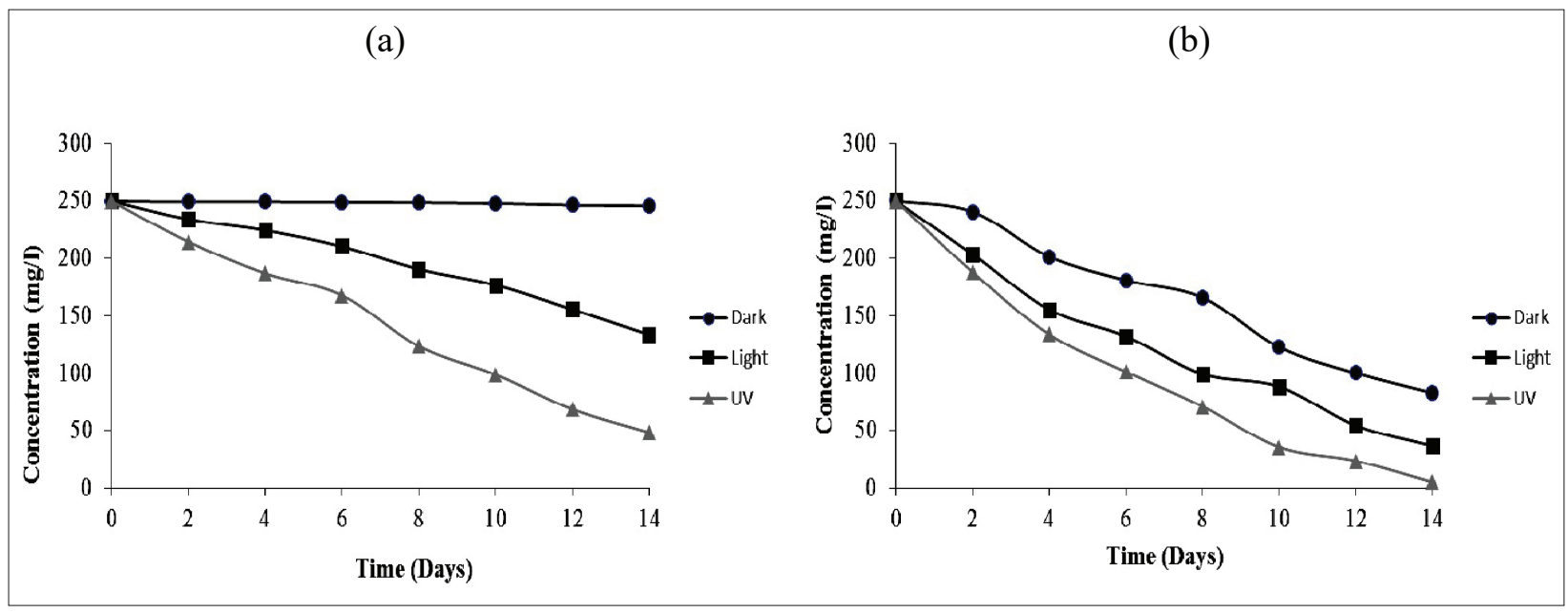

Figure 2. The effect of light on AZA degradation with and without bacteria inoculation. (a) The effect of UV light, sunlight and dark environment on AZA degradation; (b) effect of UV light, sunlight and dark environment with Corynebacterium sp. inoculation on AZA degradation. When error bars are not shown standard deviation was less than the width of the symbol.

\section{CONCLUSION}

According to the study, AZA persists in the environment in high concentrations due to the bioaccumulation and biomagnification processes where even photodegradation cannot remove the chemical from the environment naturally. Quantification of the persistence of AZA in the environment and the studies on removal methods of AZA are needed to address this issue. The results of the study indicate that application of harnessing microbes degradation of pesticides is a promising and versatile, environmentally sound treatment method to remove AZA from a contaminated environment.

\section{Acknowledgemnts}

The authors wish to thank the Centre for Water Quality and Algae Research and Department of Zoology at the University of Sri Jayewardenepura; and Waste Management Authority, Sri Lanka and the staff for all the support.

\section{REFERENCES}

Aislabie J. \& Lloyd-Jones G. (1995). A review of bacterialdegradation of pesticides. Soil Research 33(6): 925-942. DOI: https://doi.org/10.1071/SR9950925

Alberty R.A. (2011). Enzyme Kinetics: Rapid-Equilibrium Applications of Mathematica, volume 150. John Wiley and Sons, USA.

DOI: https://doi.org/10.1002/9780470940020

APHA (1999). Standard Methods for the examination of water and wastewater. American Journal of Public Health 20: 541.

Aulakh J.S., Malik A.K. \& Mahajan R.K. (2005). Solid phase micro extraction-high pressure liquid chromatographic determination of nabam, thiram and azamethiphos in water samples with UV detection. Preliminary data. Talanta 66(1): 266-270.

DOI: https://doi.org/10.1016/j.talanta.2004.11.016

Bandara N.J., Hettiaratchi J.P.A., Wirasinghe S.C. \& Pilapiiya S. (2007). Relation of waste generation and composition to socio-economic factors: a case study. Environmental Monitoring and Assessment 135(1-3): 31-39.

DOI: https://doi.org/10.1007/s10661-007-9705-3 
Baskaran S., Kookana R.S. \& Naidu R. (1997). Determination of the insecticide imidacloprid in water and soil using high-performance liquid chromatography. Journal of Chromatography A 787(1-2): 271-275. DOI: https://doi.org/10.1016/S0021-9673 (97)00652-3

Colorado B.E.J., Tobón A.B. \& Ballestas I.T. (2016). Organophosphorus pesticides degrading bacteria present in contaminated soils. Revista Ciencias Técnicas Agropecuarias 25(3): 13-22.

DOI: http://dx.doi.org/10.13140/RG.2.2.20023.73126

Dahanayaka D.D.G.L., Perera B., Wijeyaratne M.J.S. \& Tonooka H. (2016). Monitoring eutrophication trends in Bolgoda North Lake, Sri Lanka by satellite remote sensing. Turkish Journal of Fisheries and Aquatic Sciences 16(3): 563-570.

DOI: https://doi.org/10.4194/1303-2712-v16_3_08

Ekanayake E.M.M.S. \& Manage P.M. (2017). Decolorization of CI Direct Blue 201 Textile dye by native bacteria. International Journal of Multidisciplinary Studies 4(1): 49-58.

DOI: http://doi.org/10.4038/10.4038/ijms.v4i1.36

Gelman F., Binstock R. \& Halicz L. (2012). Application of the Walkley-Black titration for the organic carbon quantification in organic rich sedimentary rocks. Fuel 96: 608-610.

DOI: https://doi.org/10.1016/j.fuel.2011.12.053

Idroos F.S. \& Manage P.M. (2018). Bioremediation of microcystins by two native bacteria; Bacillus Cereus and Rahnella Aquatilis. Asian Journal of Microbiology Biotechnology and Environmental Sciences 20(3): 24-32. DOI: http://dr.lib.sjp.ac.lk/handle/123456789/7313

Jouhara H., Czajczyńska D., Ghazal H., Krzyżyńska R., Anguilano L., Reynolds A.J. \& Spencer N. (2017). Municipal waste management systems for domestic use. Energy 39: 485-506.

DOI: https://doi.org/10.1016/j.energy.2017.07.162

Kafilzadeh F., Ebrahimnezhad M. \& Tahery Y. (2015). Isolation and identification of endosulfan-degrading bacteria and evaluation of their bioremediation in Kor River, Iran. Osong Public health and Research Perspectives 6(1): 39-46. DOI: https://doi.org/10.1016/j.phrp.2014.12.003

Kalantary R.R., Mohseni-Bandpi A., Esrafili A., Nasseri S., Ashmagh F.R., Jorfi S. \& Ja'fari M. (2014). Effectiveness of biostimulation through nutrient content on the bioremediation of phenanthrene contaminated soil. Journal of Environmental Health Science and Engineering 12(1): 143.

DOI: https://doi.org/10.1186/s40201-014-0143-1

Kanazawa J. (1989). Relationship between the soil sorption constants for pesticides and their physicochemical properties. Environmental Toxicology and Chemistry: An International Journal 8(6): 477-484.

DOI: https://doi.org/10.1002/etc.5620080604

Karunarathne H.M.L.P. (2015). Municipal Solid Waste Management (MSWM) in Sri Lanka. In: Proceedings of the National Symposium on Real Estate Management and Valuation. November, 2015.
Kohzaki K., Masaoka T., Nagayama M., Akahori F., Sakaguchi K. \& Kohzaki R. (1991). Effects of azamethiphos, an organophosphorus insecticide, on serum cholinesterase activity and isoenzymes in the rat. Veterinary and Human Toxicology 33(6): 575-578.

PMID: https://pubmed.ncbi.nlm.nih.gov/1808835/

Konda L.N., Czinkota I., Füleky G. \& Morovján G. (2002). Modeling of single-step and multistep adsorption isotherms of organic pesticides on soil. Journal of agricultural and food chemistry 50(25): 7326-7331.

DOI: https://doi.org/10.1021/jf0204506

Liyanage G.Y. \& Manage P.M. (2016a). Isolation and characterization of oil degrading bacteria from coastal waters and sediments from three locations in Sri Lanka. Journal of the National Science Foundation of Sri Lanka 44(4): 201-203.

DOI: http://dx.doi.org/10.4038/jnsfsr.v44i4.8017

Liyanage G.Y. \& Manage P.M. (2016b). Optimization of environmental factors on oil degrading bacterial isolated from coastal water and sediments in Sri Lanka. Journal of Tropical Forestry and Environment 5(2):13-25.

DOI: http://dr.lib.sjp.ac.lk/handle/123456789/2950

Manage P.M., Christine E. \& Linda A.L. (2016a). Bacterial degradation of microcystin. In: Interdisciplinary Studies on Environmental Chemistry-Biological Responses to Contaminants, volume 3 (eds. N. Hamamura, S. Suzuki, S. Mendo, C. M. Barroso, H. Iwata \& S. Tanabe), pp. 97-104. TERRAPUB, Tokyo, Japan.

Manage P.M., Edwards C. \& Lawton L.A. (2016b). Biodegradation of microcystin-LR by natural bacterial populations. Interdisciplinary Studies on Environmental Chemistry-Environmental Research in Asia (eds. Y. Obayashi, T. Isobe, A. Subramanian, S. Suzuki \& S. Tanabe), pp. 277-285. TERRAPUB, Tokyo, Japan.

Manage P.M., Edwards C., Singh B.K. \& Lawton L.A. (2009). Isolation and identification of novel microcystin-degrading bacteria. Applied and Environmental Microbiology 75(21): 6924-6928.

DOI: https://doi.org/10.1128/AEM.01928-09

Manage P.M., Kawabata Z. \& Nakano S.I. (2000). Algicidal effect of the bacterium Alcaligenes denitrificans on Microcystis spp. Aquatic Microbial Ecology 22(2): 111117. DOI: https://doi.org/10.3354/ame022111

Melo C.A., Massenssini A.M., Passos A.B.R., Carvalho F.P., Ferreira L.R., Silva A.A. \& Costa M.D. (2017). Isolation and characteristics of sulfentrazone-degrading bacteria. Journal of Environmental Science and Health, Part B 52(2): 115-121.

DOI: https://doi.org/10.1080/03601234.2016.1248136

Nayanthika I.V.K., Jayawardana D.T., Bandara N.J.G.J., Manage P.M. \& Madushanka R.M.T.D. (2018). Effective use of iron-aluminum rich laterite-based soil mixture for treatment of landfill leachate. Waste Management 74: $347-$ 361 .

DOI: https://doi.org/10.1016/j.wasman.2018.01.013

Nkedi-Kizza P., Rao P.S.C. \& Hornsby A.G. (1985). Influence of organic cosolvents on sorption of hydrophobic 
organic chemicals by soils. Environmental Science and Technology 19(10): 975-979.

DOI: https://doi.org/10.1021/es00140a015

Pergal M.V., Kodranov I.D., Dojčinović B., Avdin V.V., Stanković D.M., Petković B.B. \& Manojlović D.D. (2020). Evaluation of azamethiphos and dimethoate degradation using chlorine dioxide during water treatment. Environmental Science and Pollution Research International 27: 147-160.

DOI: https://doi.org/10.1007/s11356-020-09069-5

Ray S. (2014). Bioremediation of pesticides: a case study. Microbial Biodegradation and Bioremediation, pp. 511518. Elsevier Insights, Netherlands.

DOI: https://doi.org/10.1016/B978-0-12-800021-2.00022-4

Roy A., Dutta A., Pal S., Gupta A., Sarkar J., Chatterjee A., Saha A., Sarkar P., Sar P. \& Kazy S.K. (2018). Biostimulation and bioaugmentation of native microbial community accelerated bioremediation of oil refinery sludge. Bioresource Technology 253: 22-32.

DOI: https://doi.org/10.1016/j.biortech.2018.01.004

Sarnaik S.S. (2004). Biodegradation of organophosphorus pesticides. Proceedings: Indian National Science Academy Part B 70(1): 57-70.

Singh B.K. \& Walker A. (2006). Microbial degradation of organophosphorus compounds. FEMS microbiology Reviews 30(3): 428-471.

DOI: https://doi.org/10.1111/j.1574-6976.2006.00018.x

Singh B.K. (2009). Organophosphorus-degrading bacteria: ecology and industrial applications. Nature Reviews Microbiology 7(2): 156.

DOI: https://doi.org/10.1038/nrmicro2050

Uqab B., Mudasir S. \& Nazir R. (2016). Review on bioremediation of pesticides. Journal of Bioremediation and Biodegradation 7: 343.

DOI: https://doi.org/10.4172/2155-6199.1000343

Vidanaarachchi C.K., Yuen S.T. \& Pilapitiya S. (2006). Municipal solid waste management in the Southern Province of Sri Lanka: Problems, issues and challenges. Waste Management 26(8): 920-930.

DOI: https://doi.org/10.1016/j.wasman.2005.09.013

Xu M., Zhang Q., Xia C., Zhong Y., Sun G., Guo J., Yuan T., Zhou J. \& He Z. (2014). Elevated nitrate enriches microbial functional genes for potential bioremediation of complexly contaminated sediments. The ISME Journal 8(9): 19321944.

DOI: https://doi.org/10.1038/ismej.2014.42

Yang Z., Liu Y., Liu D. \& Zhou Z. (2012). Determination of organophosphorus pesticides in soil by dispersive liquidliquid microextraction and gas chromatography. Journal of chromatographic science 50(1): 15-20.

DOI: https://doi.org/10.1093/chromsci/bmr011

Zaman A.U. (2016). A comprehensive study of the environmental and economic benefits of resource recovery from global waste management systems. Journal of Cleaner Production 124: 41-50.

DOI: https://doi.org/10.1016/j.jclepro.2016.02.086 